\title{
Screening of Kinetic Rate Equations for Gasification Simulation Models
}

\author{
Kjell-Arne Solli, Rajan Kumar Thapa, Britt Margrethe Emilie Moldestad \\ Department of Process, Energy and Environmental Technology, University College of Southeast Norway, Norway \\ kjell-arne.solli@usn.no
}

\begin{abstract}
The energy from biomass can be utilized through the thermochemical conversion process of pyrolysis and gasification. The process involves solid phase and fluid phase interactions. Computational Particle Fluid Dynamics (CPFD) tools are most commonly used for simulations. The chemical processes involved is described by reaction rate expressions and equilibrium constants. These expressions are often not well studied, but rather adapted from previous studies in lack of better knowledge. Methodology and tools are presented to aim in the selection and optimization of rate expressions for a particular process. Simulation tools for reactions in batch or plug-flow conditions are shown applicable to study selected chemical reactions in detail. Results from one such study is compared to CPFD as well as CSTR results of a gasification process. The reaction scheme for the simulation model could be simplified.
\end{abstract}

Keywords: gasification, reaction kinetics, KINSIM, Barracuda, Aspen Plus, fluidized bed

\section{Introduction}

Biomass is the oldest source of energy known to men and contributes to $14 \%$ of world's energy consumption (Bain et al., 1998; Saxena et al., 2009). Energy recovery from biomass is possible through the thermochemical conversion processes pyrolysis and gasification. In the gasification process, the biomass undergoes endothermic reactions to produce a mixture of combustible gases that is called producer gas, which can be used in gas engines, gas turbines or fuel cells to produce combined heat and electricity or it can be used as raw material in production of liquid bio fuel.

Different types of reactors can be used in the gasification process. The most efficient types are the fluidized bed reactors, and the efficiency of these reactors mainly depends on the thermo-chemical and fluid dynamic behavior in the reactor. (Olofsson et al., 2005; Pfeifer et al., 2011). The fluid dynamics depends on the gas-solid flow inside the reactor while the thermochemical behavior or reactions and their kinetics depend on the heat supply, the residence time and the gas-particle mixing in the reactor. The efficiency of the biomass-based energy technology has to be further increased to make the technology more sustainable in the world energy market, which is still dominated by fossil fuels. Study of chemical reactions and their kinetics in an operating plant or a reactor model, is difficult due to high operating temperature. Computational models are therefore used to optimize the reactors. In order to have a simulation model that predicts chemical composition, it is crucial to implement reaction schemes with reaction rates and the targeting equilibrium composition that correspond to real life conditions.

Different computational models have been used to simulate the biomass gasification process. Thapa et al. (Thapa and Halvorsen, 2014; Thapa et al., 2014) have simulated the gasification process using the Computational Particle Fluid Dynamics (CPFD) tool, by Barracuda VR15 software. Thapa implemented the set of kinetic equations developed by Snider et al (Snider $e t$ al., 2011), Kauhsal et al. (Kaushal et al., 2007), GomezBarea et al. (Gómez-Barea and Leckner, 2010) and Umeki et al. (Umeki et al., 2010) together with the stoichiometric equations in Barracuda. The results of the simulations were compared to the measured values from an existing biomass gasification plant. The CPFD methodology solves the fluid and particle equations in three dimensions. The fluid dynamics is described by averaged Navier-Stokes equations with strong coupling to the particle phase. To apply CPFD methodology for heat transfer and chemistry, an enthalpy equation is solved to calculate flows with large chemistry-induced temperature variations. The CPFD method is a hybrid numerical method, where the fluid phase is solved using Eulerian computational grid and the solids are modeled using Lagrangian computational particles (Andrews and O'Rourke, 1996; Snider, 2001).

Eikeland et al. (Eikeland et al., 2015) used the process simulation tool Aspen Plus to simulate the biomass gasification process. The reactions are simulated by using Gibbs reactor or continuous stirred tank reactor (CSTR). The Gibbs reactor only includes the stoichiometric equations, whereas the CSTR model includes both the stoichiometric equations and the related reaction rates for analysis of the producer gas composition and its heating value. Eikeland used the the set of kinetic equations developed by Umeki et al. (Umeki et al., 2010). Aspen Plus is a one-dimensional steady state simulation model. 
The aim of the current work is to investigate the sets of reaction scheme kinetics published in literature by simulating them using the ReactLab ${ }^{\text {TM }}$ KINSIM software from Jplus Consulting (Norman et al., 2016), and compare to the results of the previous works performed with CPFD and Aspen Plus (Eikeland et al., 2015; Thapa and Halvorsen, 2014).

\section{Reaction Kinetics}

For a reaction of species $\mathrm{A}$ and $\mathrm{B}$ to $\mathrm{C}$ and $\mathrm{D}$, the rate $r$ of the forward reaction is in general given by the equation

$$
r=k[A]^{a}[B]^{b}
$$

where $a$ and $b$ equals the stoichiometric coefficients for an elementary reaction, while this need not be the case for a global reaction consisting of several elemental steps. For a global reaction, the rate-limiting step may include species not present in the global rate formulation. The brackets denotes the concentration (or activities, to be precise) of species $A$ and $B$ in specified units. The rate constant $k$ is a function of temperature as well as specific conditions like the presence of a catalyst. The temperature dependence of $k$ can be described by the modified Arrhenius equation

$$
k=B T^{n} \exp ^{\frac{-E_{a}}{R T}}
$$

where $\mathrm{B}$ is a temperature-independent constant (McNaught and Wilkinson, 1997) and $\mathrm{n}$ is a number between -1 and +1 . The constant $n=0$ gives the original Arrhenius equation and then usually the letter A denotes the pre-exponential factor. The constant $E_{a}$ is the activation energy and $R$ is the universal gas constant. The reverse reaction rate is given by a similar rate equation. The thermodynamic equilibrium of a chemical reaction corresponds to forward and reverse rates being equal. Thus, denoting the reverse reaction constants with an apostrophe, the equilibrium constant $\mathrm{K}$ is given by

$$
K=\frac{k(\text { forward })}{\left.k^{\prime} \text { (reverse }\right)}=\frac{A}{A^{\prime}} \exp ^{\frac{-E_{a}+E_{a}^{\prime}}{R T}}=\frac{[C]^{c}[D]^{d}}{[A]^{a}[B]^{b}}
$$

Some reactions, like proton transfer in aqueous solutions, achieve equilibrium close to instantaneous such that product concentrations can be calculated from the equilibrium constants and mass balance. For most reactions, an equilibrium condition is not reached within available time frame, thus product concentrations must be deduced from differential equations. The solution of these may be by algebraic or stochastic methods.

\section{Previous Work}

Many of the published reaction rate expressions were developed for simulation of coal gasification processes. They have later been applied to biomass sources. In addition, the study of combustion processes involve many relevant species and expressions, and are thus applied for gasification.

\subsection{The Gasification Process}

The process for gasification of biomass can be divided in three consecutive steps; namely evaporation, pyrolysis, and gasification of resulting char product and volatiles. Both evaporation and pyrolysis proceeds close to instantaneous at the typical process temperatures of above $700{ }^{\circ} \mathrm{C}$. The products after pyrolysis can be characterized as ash, tar, char and gases. The ash fraction is mostly minerals. The tar fraction is higher molecular weight hydrocarbons including small fractions of other elements. Both the ash and tar fractions are of minor importance for the total simulation, and therefore often skipped in the simulation model. The char fraction is mostly solid carbon (C), and is usually treated as pure carbon in following reactions with the pyrolysis gases. The main gases produced from pyrolysis are water $\left(\mathrm{H}_{2} \mathrm{O}\right)$, carbon monoxide $(\mathrm{CO})$, carbon dioxide $\left(\mathrm{CO}_{2}\right)$, hydrogen $\left(\mathrm{H}_{2}\right)$ and methane $\left(\mathrm{CH}_{4}\right)$. In addition comes the water produced from evaporation. For a fluidized process to work, a fluidization gas is needed. Steam $\left(\mathrm{H}_{2} \mathrm{O}\right)$ is used in the process studied in this work, while carbon dioxide or air (oxygen, nitrogen) are commonly used in other processes.

\subsection{Kinetic Models}

The overall chemical reactions to be included in a simulation model then involve reactions between $\mathrm{C}, \mathrm{CO}$, $\mathrm{CO}_{2}, \mathrm{H}_{2}, \mathrm{CH}_{4}$ and $\mathrm{H}_{2} \mathrm{O}$. Some possible chemical reactions are listed in Table 1 and Table 2. Since oxygen is not added to the system, combustion reactions with oxygen has been omitted.

The table field Referring source points to multiple references. It has become common practice to refer to an author who in turn refers to another author and so on, and it is therefore often difficult to evaluate the relevance of the original source, see discussion below.

\subsection{Complexity of Sources for Kinetic Rate Equations}

For the rates involving solid phase, reference to the Japanese text of Watanabe (Watanabe et al., 2002) is made by Umeki et al. (Umeki et al., 2010). Snider (Snider et al., 2011) is referenced in recent work by Xie (Xie et al., 2012) and Eikeland (Eikeland et al., 2015). Snider in turn refers to Syamlal and Bissett (Syamlal and Bissett, 1992) who refers to a user's manual of a computer program by Wen et al. (Wen et al., 1982).

Wen et al. are listing 4 sets of parameters for 4 types of coal - the parameters are determined from experimental data by Elgin (Elgin, 1974). Any reference to which type of coal that is relevant has been lost in later references. 
Table 1. Chemical Reactions Involving Solid Phase (Carbon).

\begin{tabular}{|c|c|c|}
\hline $\begin{array}{l}\text { Reactions } \\
\text { Heat of reaction at } 850^{\circ} \mathrm{C}, \Delta H_{R}(\mathrm{~kJ} / \mathrm{mol})(\text { Zanzi } \\
\text { et al., 2002) }\end{array}$ & $\begin{array}{l}\text { Reaction rate forward (top) and reverse (bottom })^{a} \\
\qquad\left(\mathrm{~mol} /\left(\mathrm{m}^{3} \bullet \mathrm{s}\right), \mathrm{J}, \mathrm{K}\right)\end{array}$ & Referring source \\
\hline \multirow[t]{2}{*}{$\begin{array}{l}\text { Steam gasification (water-gas reaction): } \\
\qquad \begin{array}{c}\mathrm{C}(\mathrm{s})+\mathrm{H}_{2} \mathrm{O} \underset{+118,5}{\rightleftarrows} \mathrm{CO}+\mathrm{H}_{2} \\
\end{array}\end{array}$} & $\begin{array}{l}=1,272 m_{s} T \exp ^{\frac{-22645}{T}}\left[H_{2} O\right] \\
=1,044 \cdot 10^{-4} m_{s} T^{2} \exp ^{\left(\frac{-6319}{T}-17,29\right)}\left[H_{2}\right][C O]\end{array}$ & $\begin{array}{l}\text { Snider - Syamlal - Wen } \\
\text { (Snider et al., 2011; Syamlal } \\
\text { and Bissett, 1992; Wen et } \\
\text { al., 1982) }\end{array}$ \\
\hline & $=2,07 \cdot 10^{7} \exp ^{\frac{-220000}{R T}} p_{H_{2} O}^{0,73}$ units not given in source & $\begin{array}{l}\text { Umeki-Watanabe (Umeki } \\
\text { et al., 2010; Watanabe et } \\
\text { al., 2002) }\end{array}$ \\
\hline \multirow[t]{2}{*}{$\begin{array}{c}\mathrm{CO}_{2} \text { gasification (Boudouard reaction): } \\
\qquad \mathrm{C}(\mathrm{s})+\mathrm{CO}_{2} \underset{+159,5}{\rightleftarrows} 2 \mathrm{CO}\end{array}$} & $\begin{array}{l}=1,272 m_{S} T \exp ^{\frac{-22645}{T}}\left[\mathrm{CO}_{2}\right] \\
=1,044 \cdot 10^{-4} m_{S} T^{2} \exp \left(\frac{-2363}{T}-20,92\right)[\mathrm{CO}]^{2}\end{array}$ & Snider - Syamlal - Wen \\
\hline & $=1,12 \cdot 10^{8} \exp ^{\frac{-245000}{R T}} p_{\mathrm{CO}_{2}}^{0,31}$ units not given in source & Umeki-Watanabe \\
\hline $\begin{array}{l}\text { Methanation reaction: } \\
\qquad 0,5 \mathrm{C}(\mathrm{s})+\mathrm{H}_{2} \underset{-87,5}{\rightleftarrows} 0,5 \mathrm{CH}_{4}\end{array}$ & 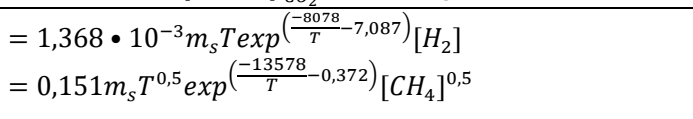 & Snider - Syamlal - Wen \\
\hline
\end{tabular}

${ }^{\mathrm{a}} m_{s}=M_{w C} \times[C(s)]$ equals mass of carbon, the approximate char component

$M_{w C}=$ molecular weight for carbon and $[C(s)]=$ molar concentration of solid carbon

Table 2. Chemical Reactions in Fluid Phase.

\begin{tabular}{|c|c|c|}
\hline $\begin{array}{l}\text { Reactions } \\
\text { Heat of reaction at } 850^{\circ} \mathrm{C}, \Delta H_{R}(\mathrm{~kJ} / \mathrm{mol})(\text { Zanzi } \\
\text { et al., 2002) }\end{array}$ & $\begin{array}{l}\text { Reaction rate forward (top) and reverse (bottom) } \\
\qquad\left(\mathrm{mol} /\left(\mathrm{m}^{3} \bullet \mathrm{s}\right), \mathrm{J}, \mathrm{K}\right)\end{array}$ & Referring source \\
\hline \multirow[t]{7}{*}{$\begin{array}{l}\text { Water-gas shift reaction: } \\
\qquad \mathrm{CO}+\mathrm{H}_{2} \mathrm{O} \underset{-33,6}{\rightleftarrows} \mathrm{CO}_{2}+\mathrm{H}_{2}\end{array}$} & $=2,78 \cdot 10^{6} \exp ^{\frac{-1516}{T}}[\mathrm{CO}]\left[\mathrm{H}_{2} \mathrm{O}\right]$ & $\begin{array}{l}\text { Gómez - Biba (Biba et al., } \\
\text { 1978; Franks, 1967; Gómez- } \\
\text { Barea and Leckner, 2010; } \\
\text { Yoon et al., 1978) }\end{array}$ \\
\hline & $\begin{array}{l}=7,68 \cdot 10^{10} \exp ^{\frac{-36640}{T}}[\mathrm{CO}]^{0,5}\left[\mathrm{H}_{2} \mathrm{O}\right] \\
=6,4 \cdot 10^{9} \exp ^{\frac{-39260}{T}}\left[\mathrm{H}_{2}\right]^{0,5}\left[\mathrm{CO}_{2}\right]\end{array}$ & $\begin{array}{l}\text { Snider - Bustamante (GRI) - } \\
\text { Moe (Bradford, 1933; } \\
\text { Bustamante et al., 2004; } \\
\text { Bustamante et al., 2005; } \\
\text { Smith et al.; Snider et al., } \\
\text { 2011) }\end{array}$ \\
\hline & $\begin{array}{l}=2,75 \cdot 10^{6} \exp ^{\frac{-10065}{T}}[\mathrm{CO}]\left[\mathrm{H}_{2} \mathrm{O}\right] \\
=6,71 \cdot 10^{7} \exp ^{\frac{-13688}{T}}\left[\mathrm{CO}_{2}\right]\left[\mathrm{H}_{2}\right]\end{array}$ & $\begin{array}{l}\text { Wang - Lindstedt - Kuo } \\
\text { (Jones and Lindstedt, 1988; } \\
\text { Kuo, 1986; Wang et al., } \\
\text { 2012) }\end{array}$ \\
\hline & $\begin{array}{l}=2,50 \bullet 10^{5} \exp ^{\frac{-16600}{T}}[\mathrm{CO}]\left[\mathrm{H}_{2} \mathrm{O}\right] \\
=2,38 \cdot 10^{3} \operatorname{Texp}^{\frac{-16600}{T}}\left[\mathrm{CO}_{2}\right]\left[\mathrm{H}_{2}\right]\end{array}$ & $\begin{array}{l}\text { Umeki - (Corella/Maki) } \\
\text { (Bustamante et al., 2005; } \\
\text { Corella and Sanz, 2005; } \\
\text { Snider et al., 2011; Umeki et } \\
\text { al., 2010) }\end{array}$ \\
\hline & $\begin{array}{l}=10^{6} \exp ^{\frac{-6370}{T}}[\mathrm{CO}]\left[\mathrm{H}_{2} \mathrm{O}\right] \\
=1,92 \cdot 10^{3} \exp ^{\frac{860}{T}}\left[\mathrm{CO}_{2}\right]\left[\mathrm{H}_{2}\right]\end{array}$ & $\begin{array}{l}\text { Corella and more (Corella } \\
\text { and Sanz, 2005; González- } \\
\text { Saiz, 1988; Simell et al., } \\
\text { 1999; Xu and Froment, 1989) } \\
\end{array}$ \\
\hline & $\begin{array}{l}=2,50 \cdot 10^{5} \exp ^{\frac{-16600}{T}}[\mathrm{CO}]\left[\mathrm{H}_{2} \mathrm{O}\right] \\
=9,43 \cdot 10^{6} \exp ^{\frac{-49500}{T}}\left[\mathrm{CO}_{2}\right]\left[\mathrm{H}_{2}\right]\end{array}$ & $\begin{array}{l}\text { Maki-Modell (Maki and } \\
\text { Miura, 1997; Modell and } \\
\text { Reid, 1974) }\end{array}$ \\
\hline & $\begin{array}{l}=2,78 \cdot 10^{6} \exp ^{\frac{-1510}{T}}[\mathrm{CO}]\left[\mathrm{H}_{2} \mathrm{O}\right] \\
=1,05 \cdot 10^{8} \exp ^{\frac{-5468}{T}}\left[\mathrm{CO}_{2}\right]\left[\mathrm{H}_{2}\right]\end{array}$ & $\begin{array}{l}\text { de Souza-Santos - Gibson - } \\
\text { Parent (de Souza-Santos, } \\
\text { 2004; Gibson and Euker, } \\
\text { 1975; Parent and Katz, 1948) }\end{array}$ \\
\hline $\begin{array}{l}\text { Methane steam reforming reaction: } \\
\qquad \mathrm{CH}_{4}+\mathrm{H}_{2} \mathrm{O} \underset{+225,5}{\rightleftarrows} \mathrm{CO}+3 \mathrm{H}_{2}\end{array}$ & $=3,0 \bullet 10^{5} \exp ^{\frac{-15042}{T}}\left[\mathrm{CH}_{4}\right]\left[\mathrm{H}_{2} \mathrm{O}\right]$ & $\begin{array}{l}\text { Gómez - Lindstedt (Gómez- } \\
\text { Barea and Leckner, 2010; } \\
\text { Jones and Lindstedt, 1988; } \\
\text { Yoon et al., 1978) }\end{array}$ \\
\hline
\end{tabular}




\begin{tabular}{|c|c|c|}
\hline $\begin{array}{l}\text { Reactions } \\
\text { Heat of reaction at } 850^{\circ} \mathrm{C}, \Delta H_{R}(\mathrm{~kJ} / \mathrm{mol})(\text { Zanzi } \\
\text { et al., 2002) }\end{array}$ & $\begin{array}{l}\text { Reaction rate forward (top) and reverse (bottom) } \\
\qquad\left(\mathrm{mol} /\left(\mathrm{m}^{3} \bullet \mathrm{s}\right), \mathrm{J}, \mathrm{K}\right)\end{array}$ & Referring source \\
\hline & $\begin{array}{l}=3,1005 \exp ^{\frac{-15000}{T}}\left[\mathrm{CH}_{4}\right]\left[\mathrm{H}_{2} \mathrm{O}\right] \\
=3,556 \cdot 10^{-3} \operatorname{Texp}^{\frac{-15000}{T}}[\mathrm{CO}]\left[\mathrm{H}_{2}\right]^{2}\end{array}$ & $\begin{array}{l}\text { Umeki - (Corella) (Corella } \\
\text { and Sanz, 2005; Fletcher et } \\
\text { al., 2000; Gómez-Barea and } \\
\text { Leckner, 2010; Jones and } \\
\text { Lindstedt, 1988; Liu and } \\
\text { Gibbs, 2003; Thérien et al., } \\
\text { 1987; Umeki et al., 2010) }\end{array}$ \\
\hline & $\begin{array}{l}=3,10 \cdot 10^{-5} \exp ^{\frac{-15000}{T}}\left[\mathrm{CH}_{4}\right]\left[\mathrm{H}_{2} \mathrm{O}\right] \\
=1,17 \cdot 10^{-3} \exp ^{\frac{-47900}{T}}[\mathrm{CO}]\left[\mathrm{H}_{2}\right]^{3}\end{array}$ & revised Umeki - (Lindstedt) \\
\hline & $\begin{array}{l}=9,1 \cdot 10^{7} \exp ^{\frac{-15800}{T}}\left[\mathrm{CH}_{4}\right]\left[\mathrm{H}_{2} \mathrm{O}\right] \\
=5,52 \cdot 10^{-6} \exp ^{\frac{211200}{T}}[\mathrm{CO}]\left[\mathrm{H}_{2}\right]^{3}\end{array}$ & $\begin{array}{l}\text { Maki (Maki and Miura, 1997; } \\
\text { Modell and Reid, 1974) }\end{array}$ \\
\hline
\end{tabular}

For the water-gas shift reaction, the several sources for the reaction rate expression shows a wide variety of reaction rates. Eikeland et al. (Eikeland et al., 2015) refer to Umeki et al. (Umeki et al., 2010). Umeki at al. refers to Corella and Sans (Corella and Sanz, 2005), but are using the GRI expressions referred by Snider et al. (Snider et al., 2011) from Bustamante (Bustamante et al., 2004; Bustamante et al., 2005). Xie et al. (Xie et al., 2012) refers to Gómez-Barea and Leckner (GómezBarea and Leckner, 2010), who refers to Biba et al. (Biba et al., 1978) referring to a book by Franks (Franks, 1967).

Biba et al. (Biba et al., 1978) points out that values determined by experiments for the frequency factor cited in the literature are strictly dependent on the form of the carbonaceous material being examined, on the specific surface area, and on the corresponding value of activation energy. They have chosen mean values of literature data, and then made a sensitivity analysis for their mathematical model. Any reference to which type of coal that is relevant has been lost in later references.

The history for kinetic parameters used for the methane steam reforming reaction is similar to preceding text. In addition, it seems that a typing error is introduced by Corella and Sans (Corella and Sanz, 2005) and later referenced by Umeki et al. and Eikeland et al. Corella and Sans refers to work by Thérien et al. (Thérien et al., 1987) and Liu and Gibbs (Liu and Gibbs, 2003) from Fletcher et al. (Fletcher et al., 2000) which includes a reference to Jones and Lindstedt (Jones and Lindstedt, 1988). The typing errors have been corrected in the "revised Umeki-(Lindstedt) source" in Table 2.

\subsection{Chemical Equilibria}

For reactions that are kinetically restricted and far from equilibrium conditions, only the forward reaction rate is significant. This should, of course, be verified by comparing calculated forward and reverse rates at the simulation conditions.

The water-gas shift reaction is relatively fast (although slower than oxygen combustion) and both forward and reverse rates as well as the equilibrium constant is relevant for most simulation conditions. Bustamante et al. (Bustamante et al., 2005) points out that the wide range of kinetic parameters found in literature is due to varying catalytic effect from surfaces present at experimental conditions. Typically, carbon surfaces or deposits and nickel-containing steel (like Hastelloy $($ ) as well as minerals in ash are shown to have catalytic effect on the reaction, resulting in high reaction rates. The expression for the equilibrium constant of the water-gas shift reaction from several sources are shown in Table 3. The last line source, Callaghan (Callaghan, 2006), is a recent thesis covering the details about the water-gas shift reaction, and presumably represents reliable knowledge about the equilibrium constant for the reaction.

\section{Example Screening of Kinetic Rate Equations}

In order to have a simulation model that predicts chemical composition, both the reaction rate kinetics and the targeting equilibrium composition should correspond to real life conditions. Taken the vast difference among literature data, the choice of kinetic rate expressions is not straight forward.

Figure 1 compares the equilibrium constant value, $K_{e q}$, for the water-gas shift reaction based on selected literature data from Table 3. A positive value of $\log K_{e q}$ corresponds to the forward reaction being favored. The reaction is a moderately exothermic reversible reaction, therefore with increasing temperature the reaction rate increases but the conversion of reactants to products becomes less favorable. It is evident from Figure 1 that some sources are using an equilibrium constant not consistent with reliable data. On the other hand, if equilibrium conditions are not reached, the simulation model may still perform sufficiently well. That is, if the reaction rate expressions can reproduce the chemical reactions at present conditions. 
Table 3. Expressions for Equilibrium Constant

\begin{tabular}{|c|c|}
\hline Water-gas shift reaction: $\mathrm{CO}+\mathrm{H}_{2} \mathrm{O} \rightleftharpoons \mathrm{CO}_{2}+\mathrm{H}_{2}$ & \\
\hline $\begin{array}{c}\text { Equilibrium constant, calculated as } \frac{k_{\text {forward }}}{k_{\text {reverse }}} \text { (top) } \\
\text { and as referred from source (bottom) } \\
\left(\mathrm{mol} /\left(\mathrm{m}^{3} \circ \mathrm{s}\right), \mathrm{KJ}\right)\end{array}$ & Referring source \\
\hline $\begin{array}{l}\text { Used: } K=2,65 \cdot 10^{-2} \exp ^{\left(\frac{3958}{T}\right)} \text { (ref Biba) } \\
\text { Source (ref to Yoon): } K=0,029 \exp ^{\frac{4094}{T}}\end{array}$ & $\begin{array}{l}\text { Gómez - Biba } \\
\text { (Biba et al., 1978; } \\
\text { Franks, 1967; } \\
\text { Gómez-Barea and } \\
\text { Leckner, 2010; } \\
\text { Yoon et al., 1978) } \\
\end{array}$ \\
\hline $\begin{array}{l}\text { Used: } K=12,0 \exp ^{\left(\frac{2620}{T}\right)} \\
\text { Source: } K_{e q}=\exp ^{-4,33+\frac{4577,8}{T}}\end{array}$ & $\begin{array}{l}\text { Snider - Busta- } \\
\text { mante (GRI) - Moe } \\
\text { (Bradford, 1933; } \\
\text { Bustamante } \text { et al., } \\
\text { 2004; Bustamante } \\
\text { et al., 2005; Smith } \\
\text { et al.; Snider et al., } \\
\text { 2011) } \\
\end{array}$ \\
\hline $\begin{array}{l}K=4,10 \cdot 10^{-2} \exp ^{\left(\frac{2620}{T}\right)} \quad \text { (Fitted data, Ref: } \\
\text { Kuo) }\end{array}$ & $\begin{array}{l}\text { Wang - Lindstedt - } \\
\text { Kuo (Jones and } \\
\text { Lindstedt, 1988; } \\
\text { Kuo, 1986; Wang } \\
\text { et al., 2012) }\end{array}$ \\
\hline $\begin{array}{l}\text { Used: } K=4,10 \cdot 10^{-2} \frac{1}{T} \\
\text { Shown in forward rate: } K=2,65 \cdot 10^{-2}\left(\frac{3958}{T}\right)\end{array}$ & $\begin{array}{l}\text { Umeki - } \\
\text { (Corella/Maki) } \\
\text { (Bustamante et al., } \\
\text { 2005; Corella and } \\
\text { Sanz, 2005; Snider } \\
\text { et al., 2011; Umeki } \\
\text { et al., 2010) } \\
\end{array}$ \\
\hline $\begin{array}{l}\text { Source: } K=520 \exp ^{\frac{-7230}{T}} \text { below } 1123^{\circ} \mathrm{C} \\
\text { Source: } K=0,0027 \exp ^{\frac{-3960}{T}} \text { above } 1123^{\circ} \mathrm{C}\end{array}$ & $\begin{array}{l}\text { Corella and more } \\
\text { (Corella and Sanz, } \\
\text { 2005; González- } \\
\text { Saiz, 1988; Simell } \\
\text { et al., 1999; Xu and } \\
\text { Froment, 1989) } \\
\end{array}$ \\
\hline$K=2,65 \cdot 10^{-2} \exp ^{\left(\frac{32900}{T}\right)}$ & $\begin{array}{l}\text { Maki - Modell } \\
\text { (Maki and Miura, } \\
\text { 1997; Modell and } \\
\text { Reid, 1974) } \\
\end{array}$ \\
\hline$K=2,65 \cdot 10^{-2} \exp \frac{\left(\frac{3958}{T}\right)}{2}$ & $\begin{array}{l}\text { de Souza-Santos - } \\
\text { Gibson - Parent } \\
\text { (de Souza-Santos, } \\
\text { 2004; Gibson and } \\
\text { Euker, 1975; } \\
\text { Parent and Katz, } \\
\text { 1948) } \\
\end{array}$ \\
\hline $\log (K)=-2,418+0,0003855 \times T+\frac{2180,6}{T}$ & $\begin{array}{l}\text { Callaghan } \\
\text { (Callaghan, 2006) }\end{array}$ \\
\hline
\end{tabular}

The following discussion on reaction rates takes as an example the feed inlet conditions for a fluidized reactor as described by Eikeland (Eikeland et al., 2015) and is comparable by work of Thapa (Thapa et al., 2014). Figure 2 compares the initial reaction rates based on composition at inlet to the reactor and selected reaction scheme. Again, the vast variation in source data is evident. The rate expressions used by Snider from Bustamante is close to the non-catalyzed reaction rates found experimentally by Bustamante (Bustamante et al., 2005). Higher reaction rates presumably are deduced from catalytic conditions. Therefore, a simulation model should include rate expressions from sources that resembles the conditions of the target reactor and biomass feed.

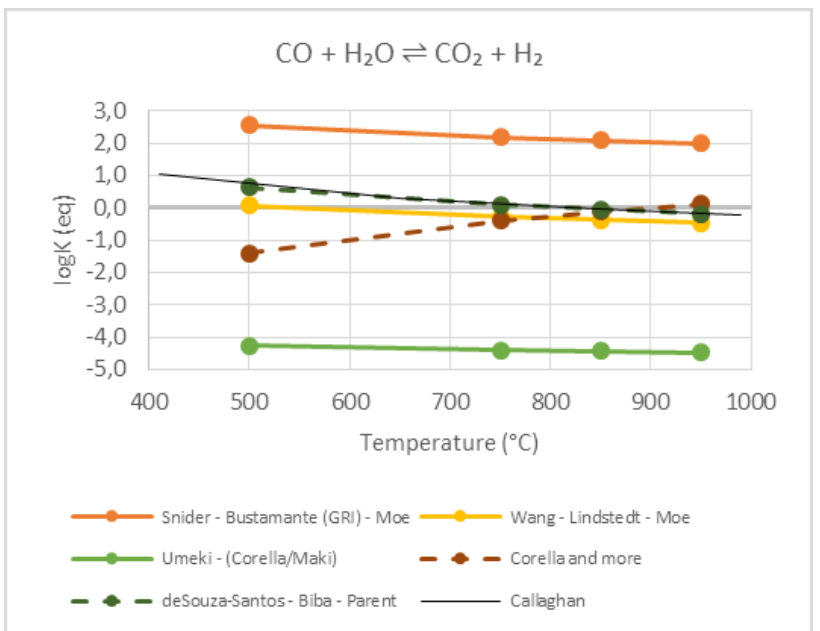

Figure 1. Equilibrium constant for water-gas shift reaction

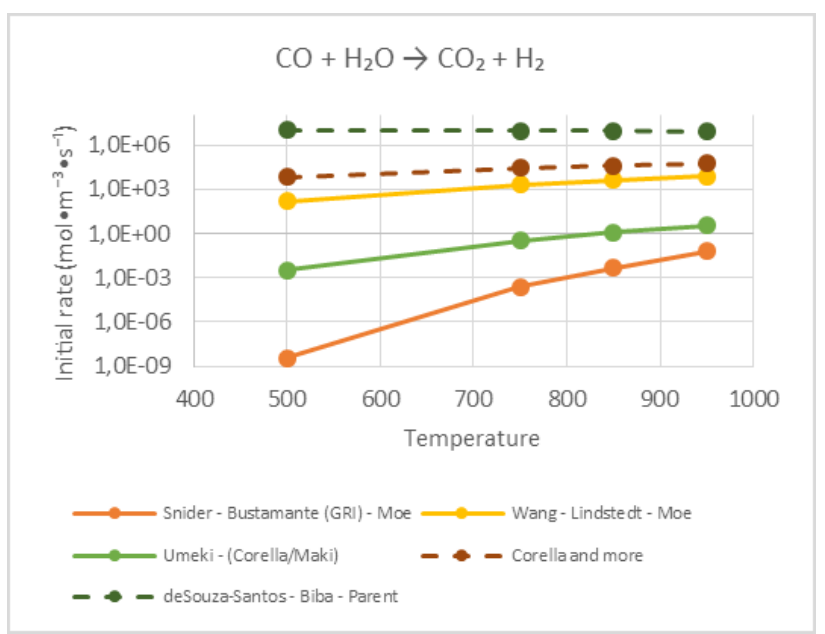

Figure 2. Initial rate of water-gas shift reaction at feed inlet conditions as described by Eikeland (Eikeland et al., 2015).

\subsection{KINSIM simulation software}

The ReactLab ${ }^{\mathrm{TM}}$ KINSIM software from Jplus Consulting (Norman et al., 2016) is one of several software packages available. The software uses MS-Office Excel as frontend to a compiled application of MatLabß. Any defined equilibria is treated as instantaneous, while differential equations for the forward and reverse reaction rates are solved.

\subsection{Kinetics}

The set of rate expressions used by Thapa (Thapa et al., 2014) together with calculated molar concentrations at inlet feed conditions have been used for time profile simulation of rate expressions. The KINSIM software has been used. The results resemble a batch or plug flow reactor. The residence time $12 \mathrm{~s}$ has been chosen to have a conversion comparable to results from Aspen Plus CSTR and Barracuda simulations by Eikeland and Thapa. In addition, simulations with residence time 
$300 \mathrm{~s}$ is shown to get an impression of semi-equilibrium conditions. See Figure 3 to Figure 6.

The Figure 3 to Figure 4 show the water-gas shift reaction to be dominating in consuming $\mathrm{CO}$ and water while producing $\mathrm{H}_{2}$ and $\mathrm{CO}_{2}$. Still, the semi-equilibrium conditions may not be reached until about $100 \mathrm{~s}$. The total conversion of carbon is strongly limited using this set of rate expressions, and other reactions do not contribute significantly as seen by the very small change in $\mathrm{CH}_{4}$ concentration. Actually, this imply that a similar simulation result can be obtained by simulating only the water-gas shift reaction. Results including only watergas shift reaction and water-gas reaction are shown in Figure 5 to Figure 6. At $12 \mathrm{~s}$ residence time, the results are identical to the full set of rate expressions. Of course, at $300 \mathrm{~s}$ residence time the lacking effect of other reactions are evident, the included carbon conversion reaction is very low.

Figure 7 shows the composition change during the gasification process as simulated at $850{ }^{\circ} \mathrm{C}$ by Aspen Plus CSTR, Barracuda CFD and KINSIM plug-flow reactor conditions.

The pyrolysis step corresponds to presumptions for this step made by Thapa and Eikeland (Eikeland et al., 2015; Thapa et al., 2014). In addition, the steam to feed ratio is kept at 1 to 1 weight dry basis. A residence time of $17 \mathrm{~s}$ was used for the CSTR conditions, while fluid residence time by Barracuda simulation is estimated to minimum $20 \mathrm{~s}$. The particle residence time is much higher. The last set of results are from using KINSIM with only two rate expressions as shown above. The Barracuda simulation give results that is in between Aspen CSTR and KINSIM plug-flow results while applying the same rate expressions. This is consistent with fluid flow in a fluidized bed reactor be described partly as plug-flow and partly as stirred tank reactor.

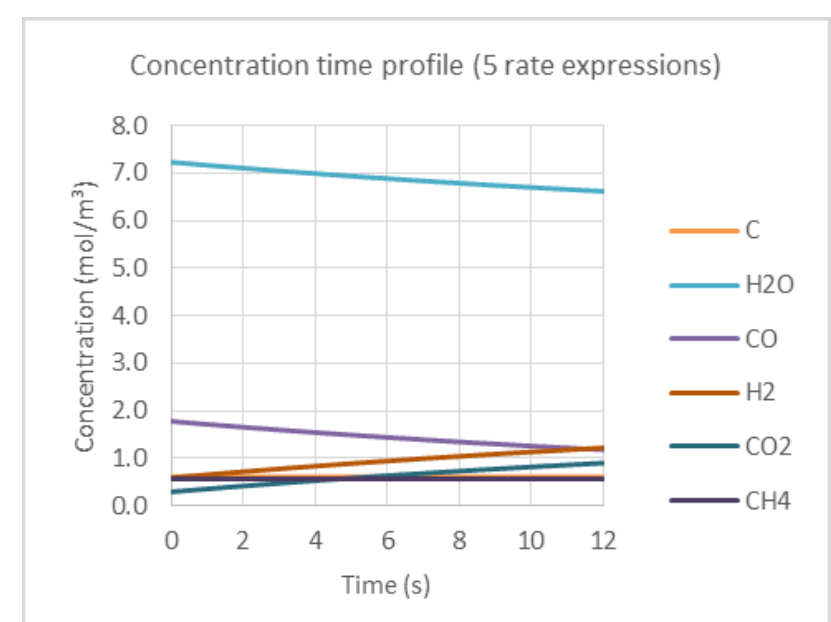

Figure 3. Concentration time profile for the full 5 sets of rate expressions (short time).

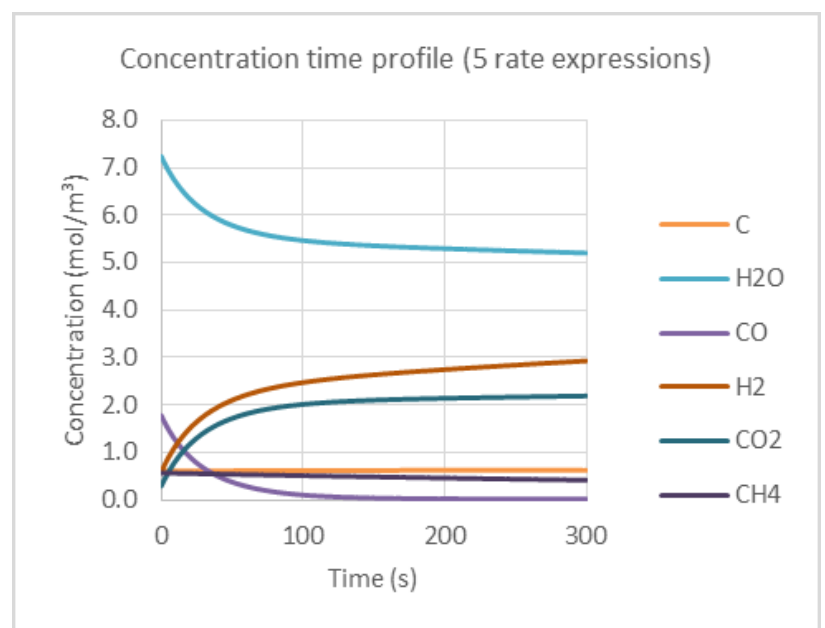

Figure 4. Concentration time profile for the full 5 sets of rate expressions (semi-equilibrium time).

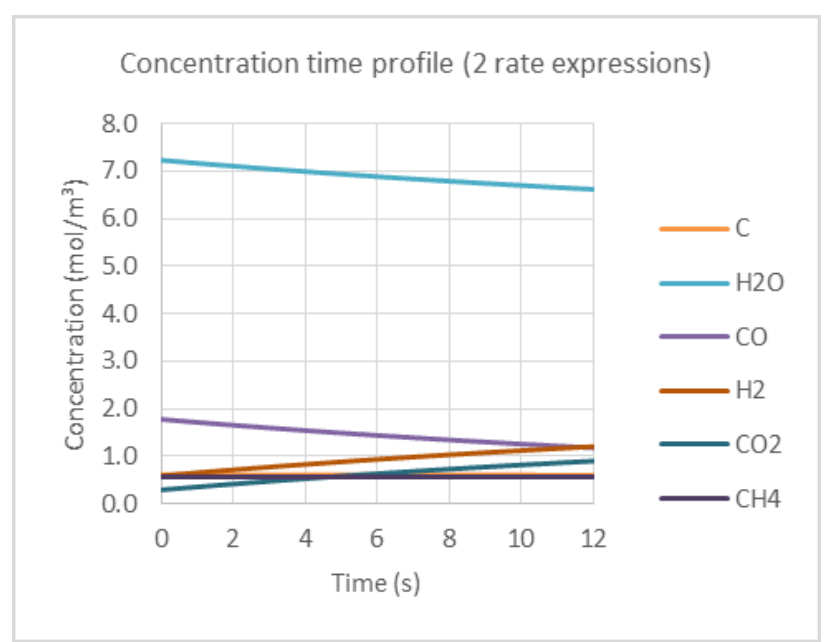

Figure 5. Concentration time profile for only 2 sets of rate expressions (short time).

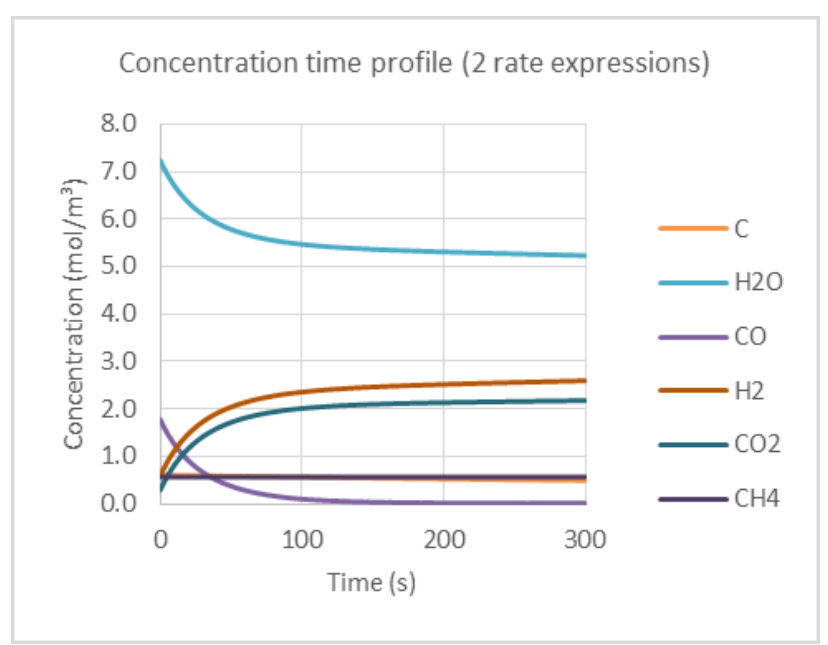

Figure 6. Concentration time profile for only 2 sets of rate expressions (semi-equilibrium time). 


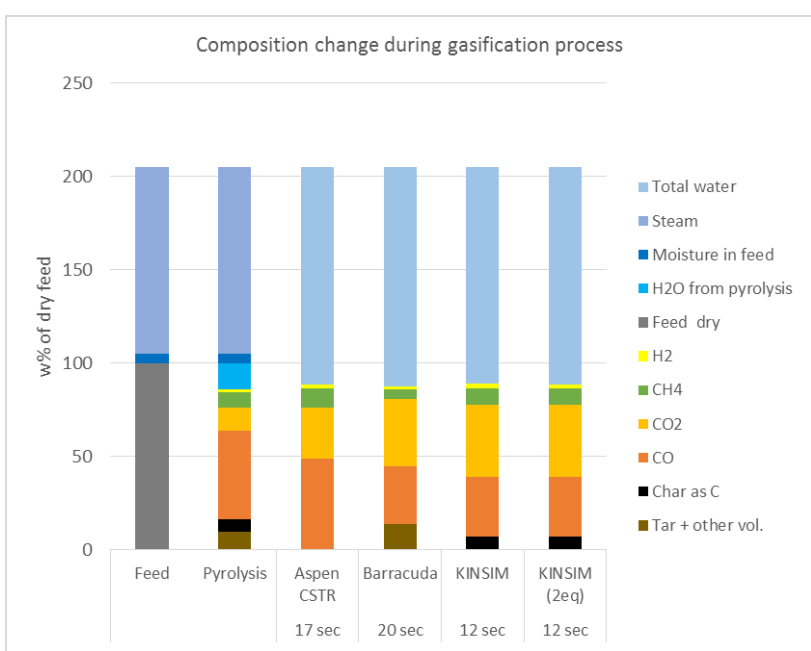

Figure 7. Composition change during a gasification process, feed and steam to outlet stream.

\section{Conclusions}

The evaluation and screening of candidate rate expressions to be used in a reactor simulation is made difficult by the obscure definition of experimental conditions as background to defined rate expressions. A lightweight tool like KINSIM and others are useful for comparison of several rate expressions and by that evaluate how significant they will contribute to the total simulation. In addition, knowledge about concentrations, residence times and real life results should be used to choose suitable set of rate expressions.

The 5 set reaction scheme studied here could be simplified to 2 sets of reactions by removing those reactions of minimal contribution to overall reaction.

\section{References}

M. J. Andrews and P. J. O'Rourke. The multiphase particlein-cell (MP-PIC) method for dense particle flow. International Journal of Multiphase Flow, 22:379-402, 1996.

R. L. Bain, R. P. Overend, and K. R. Craig. Biomass-fired power generation. Fuel Processing Technology, 54:1-16, 1998. doi: 10.1016/S0378-3820(97)00058-1

V. Biba, J. Macak, E. Klose, and J. Malecha. Mathematical model for the gasification of coal under pressure. Industrial \& Engineering Chemistry Process Design and Development, 17(1):92-98, $1978 . \quad$ doi: 10.1021/i260065a017

B. W. Bradford. The water-gas reaction in low-pressure explosions. J. Chem. Soc.:1557, 1933.

F. Bustamante, R. M. Enick, A. V. Cugini, R. P. Killmeyer, B. H. Howard, K. S. Rothenberger, M. V. Ciocco, B. D. Morreale, S. Chattopadhyay, and S. Shi. High-temperature kinetics of the homogeneous reverse water-gas shift reaction. AIChE Journal, 50(5):1028-1041, 2004. doi: 10.1002/aic.10099

F. Bustamante, R. M. Enick, R. P. Killmeyer, B. H. Howard, K. S. Rothenberger, A. V. Cugini, B. D. Morreale, and M. V. Ciocco. Uncatalyzed and wall-catalyzed forward water- gas shift reaction kinetics. AIChE Journal, 51(5):14401454, 2005. doi: 10.1002/aic.10396

C. A. Callaghan. Kinetics and Catalysis of the Water-GasShift Reaction: A Microkinetic and Graph Theoretic Approach. PhD Thesis: Worcester Polytechnic Institute. Worcester, 2006.

J. Corella and A. Sanz. Modeling circulating fluidized bed biomass gasifiers. A pseudo-rigorous model for stationary state. Fuel Processing Technology, 86(9):1021-1053, 2005. doi: 10.1016/j.fuproc.2004.11.013

M. L. de Souza-Santos. Solid Fuels Combustion and Gasification: Modeling, Simulation, and Equipment Operation. New York, NY, USA, Marcel Dekker Inc. 2004.

M. S. Eikeland, R. K. Thapa, and B. M. Halvorsen. Aspen Plus Simulation of Biomass Gasification with known Reaction Kinetic. In Proceedings of the 56th Conference on Simulation and Modelling (SIMS 56). Linköping, Sweden, Linköping University Electronic Press, Linköpings universitet, pages 149-155, 2015. doi: 10.3384/ecp 15119149

D. C. Elgin. Results of Trials of American Coals in Lurgi Pressure Gasification Plant of Westfield, Scotland. In Sixth Synthetic Pipeline Gas Symposium. Chicago, Illinois, 1974.

D. F. Fletcher, B. S. Haynes, F. C. Christo, and S. D. Joseph. A CFD based combustion model of an entrained flow biomass gasifier. Applied Mathematical Modelling, 24(3):165-182, 2000. doi: 10.1016/S0307-904X(99)000256

R. G. E. Franks. Mathematical Modelling in Chemical Engineering. New York, N.Y., Wiley, Inc. 1967.

M. A. Gibson and C. A. Euker. Mathematical Modeling of Fluidized Bed Coal Gasification. In AIChE Meeting. Los Angeles, CA, USA, 1975.

A. Gómez-Barea and B. Leckner. Modeling of biomass gasification in fluidized bed. Progress in Energy and Combustion Science, 36(4):444-509, 2010. doi: 10.1016/j.pecs.2009.12.002

J. González-Saiz. Advances in biomass gasification in fluidized bed. $\mathrm{PhD}$ Thesis: University of Saragossa. Saragossa, 1988.

W. P. Jones and R. P. Lindstedt. Global reaction schemes for hydrocarbon combustion. Combustion and Flame, 73(3):233-249, 1988. doi: 10.1016/0010-2180(88)90021-1

P. Kaushal, T. Proll, and H. Hofbauer. Modelling and simulation of biomass fired duel fluidized bed gasifier at Gussing/Austria. In International Conference on Renewable Energies and Power Quality. Sevilla, RE\&PQJ, pages 300-306, 2007. doi: 10.24084/repqj05.279

K. K. Kuo. Principles of Combustion. New York, John Wiley \& Sons. 1986.

H. Liu and B. M. Gibbs. Modeling NH3 and HCN emissions from biomass circulating fluidized biomass gasifiers. Fuel, 82:1591-1604, 2003.

T. Maki and K. Miura. A Simulation Model for the Pyrolysis of Orimulsion. Energy \& Fuels, 11(4):819-824, 1997. doi: $10.1021 / \mathrm{ef} 9601834$

A. D. McNaught and A. Wilkinson. In IUPAC. Compendium of Chemical Terminology, 2nd ed. (the "Gold Book"). 
Oxford, Blackwell Scientific Publications. 1997. doi: $10.1351 /$ goldbook

M. Modell and R. C. Reid. Thermodynamics and its applications. Englewood Cliffs, N.J, Prentice-Hall. 1974.

S. Norman, P. King, and M. Maeder. ReactLab KINSIM. Jplus Consulting Pty Ltd. 2016. Available via http://jplusconsulting.com/products/reactlab-kinsim/

I. Olofsson, A. Nordin, and U. Soderlind. Initial Review and Evaluation of Process Technologies and System Suitable for Cost-Efficient Medium-Scale Gasification for Biomass to Liquid Fuels. Master Thesis: University of Umeå, 2005.

J. D. Parent and S. Katz. Equilibrium Compositions and Enthalpy Changes for the Reaction of Carbon, Oxygen and Steam. IGT Research Bulletin, 1948.

C. Pfeifer, S. Koppatz, and H. Hofbauer. Steam gasification of various feedstocks at a dual fluidised bed gasifier: Impacts of operation conditions and bed materials. Biomass Conversion and Biorefinery, 1:39-53, 2011. doi: 10.1007/s13399-011-0007-1

R. C. Saxena, D. K. Adhikari, and H. B. Goyal. Biomassbased energy fuel through biochemical routes: A review. Renewable and Sustainable Energy Reviews, 13:167-178, 2009. doi: 10.1016/j.rser.2007.07.011

P. A. Simell, E. K. Hirvensalo, S. T. Smolander, and A. O. Krause. Steam reforming of gasification gas tar over dolomite with benzene as a model compound. Industrial and Engineering Chemistry Research, 38:1250, 1999.

G. P. Smith, D. M. Golden, M. Frenklach, N. W. Moriarty, B. Eiteneer, M. Goldenberg, C. T. Bowman, R. K. Hanson, S. Song, W. C. Gardiner, Jr, V. V. Lissianski, and Z. Qin. GRIMech 3.0. Available via http://www.me.berkeley.edu/gri_mech/

D. M. Snider. An Incompressible Three-Dimensional Multiphase Particle-in-Cell Model for Dense Particle Flows. Journal of Computational Physics, 170:523-549, 2001. doi: $10.1006 /$ jcph.2001.6747

D. M. Snider, S. M. Clark, and P. J. O'Rourke. EulerianLagrangian method for three-dimensional thermal reacting flow with application to coal gasifiers. Chemical Engineering Science, 66(6):1285-1295, 2011. doi: 10.1016/j.ces.2010.12.042

M. Syamlal and L. A. Bissett. METC Gasifier Advanced Simulation (MGAS) model. 1992. Retrieved from: http://www.osti.gov/scitech//servlets/purl/10127635$7 \mathrm{FCHVc} /$

R. K. Thapa and B. M. Halvorsen. Stepwise analysis of reactions and reacting flow in a dual fluidized bed gasification reactor. In 10th International Conference on Advances in Fluid Mechanics. Spain, WIT Transactions on Engineering Sciences, pages 37-48, 2014. doi: 10.2495/AFM140041

R. K. Thapa, C. Pfeifer, and B. M. Halvorsen. Modeling of reaction kinetics in bubbling fluidized bed biomass gasification reactor. The International Journal of Energy and Environment, 5(1):35-44, 2014. Retrieved from: http://www.ijee.ieefoundation.org/

N. Thérien, P. Marchand, A. Chamberland, and G. Gravel. Computer modeling and simulation of a biomass fluidized bed gasifier. In Proceedings of the XVIII Congress: The Use of Computers in Chemical Engineering-CEF87. Gianardi Naxos, Italy, pages 187-192, 1987.

K. Umeki, K. Yamamoto, T. Namioka, and K. Yoshikawa. High temperature steam-only gasification of woody biomass. Applied Energy, 87(3):791-798, 2010. doi: 10.1016/j.apenergy.2009.09.035

L. Wang, Z. Liu, S. Chen, and C. Zheng. Comparison of Different Global Combustion Mechanisms Under Hot and Diluted Oxidation Conditions. Combustion Science and Technology, 184(2):259-276, 2012. doi: 10.1080/00102202.2011.635612

H. Watanabe, M. Ashizawa, M. Otaka, S. Hara, and A. Inumaru. Development on numerical simulation technology of heavy oil gasifier. CRIEPI reports W01023, 2002.

C. Y. Wen, H. Chen, and M. Onozaki. User's manual for computer simulation and design of the moving-bed coal gasifier. Final report. 1982. Retrieved from: http://www.osti.gov/scitech//servlets/purl/6422177trF8L6/

J. Xie, W. Zhong, B. Jin, Y. Shao, and H. Liu. Simulation on gasification of forestry residues in fluidized beds by Eulerian-Lagrangian approach. Bioresource Technology, 121:36-46, 2012. doi: 10.1016/j.biortech.2012.06.080

J. Xu and G. F. Froment. Methane steam reforming, methanation and water-gas shift: I. Intrinsic kinetics. AIChE Journal, 35(1):88-96, 1989.

H. Yoon, J. Wei, and M. M. Denn. A model for moving-bed coal gasification reactors. AIChE Journal, 24(5):885-903, 1978. doi: $10.1002 /$ aic. 690240515

R. Zanzi, K. Sjöström, and E. Björnbom. Rapid pyrolysis of agricultural residues at high temperature. Biomass and Bioenergy, 23(5):357-366, 2002. doi: 10.1016/S09619534(02)00061-2 